\title{
定常条件下における各種木材の含水率と腐朽の関係 木質系建築材料における腐朽現象の定量化とダメージの数学的予測モデルに関する研究（第 1 報） THE RELATIONSHIP BETWEEN WATER CONTENT AND DECAY OF VARIOUS WOODS UNDER HYGROTHERMAL STEADY STATE
}

Studies on the quantification of decay phenomenon in wood-base building material and its mathematical prediction mode (Part 1)

\author{
鈴木大隆 ${ }^{* 1}$, 北谷幸恵 ${ }^{* 2}$, 岩前 篤*3, 永井久也*4 \\ 小南和 也*5 , 坂本雄三*6
}

\section{Hirotaka SUZUKI, Yukie KITADANI, Atsushi IWAMAE, Hisaya NAGAI, Kazuya KOMINAMI and Yuzo SAKAMOTO}

\begin{abstract}
There are two points of view for the prevention design of moisture problem in the building insulated envelope. One is the strictly prevention of high moisture condition in the insulated wall cavity. The other one is the permission of short-term high moisture condition, condensation and high moisture content of the wooden material as long as keeping physical durability. If the later standpoint were chosen, the insulated envelope design of every variety for Japan would be possible. Nevertheless, there are no criteria to estimate the damage of physical durability of wood by the biological factors related high moisture condition.

The points of this paper are as follows;

1) The importance of estimation damage of woods by the moisture problems is describes.

2) 2 case of hygrothermal steady state experiments were done to get basic acknowledge of woods damage by biological factors considering term, water content, temperature and humidity, physical durability.
\end{abstract}

Keywords : Building insulated envelope, Hygrothermal steady state, Water content, Wood strength, Wood decay, 断熱壁体，定常状態，含水率，木材強度，木材腐朽

\section{1. はじめに}

断熱壁体の湿害評価に関しては，壁内の温湿度性状のみならず 種々の環境条件下に晒される木材等の壁体構成材料も含めた湿害評 価を行うことが重要といえる。しかし，後者に対する既往の知見が そしいため, これまでは, 壁内では一時的な結露や高湿度・高含水 な状況は容認しないという考え方に基づき評価・開発されることが 多い。一方, 土壁造住宅や地盤防湿を行わない床下構造等, 温暖多 湿・多雨なわが国の伝統的外皮の中には，材料が初期的に保有する 水分の発湿による初期的な高湿環境, 結露は許容しながら長期的な 耐久性を保つという考え方の上に成立してきた技術も少なくない。 また，ある一定の環境下では「結露や高湿度な壁内環境は許容しな いという考え方に基づき開発された断熱外皮においても，竣工当 初は材料が初期的に保有する水分や施工中の降雨水などの影響, 運 用開始後は室内温湿度性状や雨水・設備漏水の影響により, 壁内で 初期結露や一時的な高湿度な状況に維持される危険性は十分にある。

湿害防止を目的した断熱外皮開発では，「わずかな結露・高湿な 状態も許容しない」という考え方を前提にした研究や技術構築も重 要だが，外皮が晒される様々な環境を勘案すると，その実現は必ず しも容易なことではない。むしろ, 初期結露を含む一時的結露や高 湿な状態は「どこまで許容されるのか,, 寸なわち, 寒冷地の初期の 断熱住宅で生じた内部結露による湿害, 我が国の住宅・建築で数多 く発生している降雨水や設備配管の漏水などによる湿害など，木造 住宅の構造安全性に支障を与えるような「許容できない結露」の条 件を明らかにした上で,「耐久上支障の無い結露は容認する」という
考え方を前提に外皮設計を行う方が, 壁体の湿害安全性は高くなり， 実用的といえる。建築材料の中では，金属やコンクリート材料等の 無機系材料や断熱材に関しては，使用環境条件と長期性能（発錆や 中性化による物性変化）に関する知見は整備されつつあるが，建築 躯体内に晒される木質材料の腐朽菌類等による生物劣化予測に関す る既往研究は少ないのが現状である。例えば, 純粋培養菌を木片に付

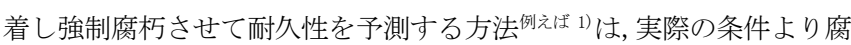
朽の進行は早いと予想される。また, 気中の胞子を木片に自然付着し腐 朽させるという実験もいくつか試みられているが例えば 2,3), 実験条件が限 られており，建築分野の耐久性予測にそのまま適用寸るのは難しい。

本研究は，主に木造建築で用いられる各種木材及び合板等の構造 用面材などの木質系材料を対象に，各材料の物理強度の低下をもた らす腐朽現象に着目し, どのような建築環境条件[材料の重量含水率, 温湿度 (定常・非定常), 水分量, 経過時間など]下で, ぞの程度の確 率で生じるのかを実験的に明らかにし，対象材料毎に生物劣化によ る物理強度が低下寸る危険性を, 上記環境条件をパラメーターとし ながら確率的に表現する関数式を開発することを主な目的とする。

本報 (第1報) では，本研究における断熱壁体の湿害防止に対する リスクコントロールの概念を述べ，この概念に基づき実施した各種 木材試験体を用いた木材耐久性実験の全体概要，及び定常条件下で の実験結果について報告を行う。

\section{2. 湿害防止に対するリスクコントロールの考え方と実験計画 2-1＼cjkstart湿害防止に対するリスクコントロールの考え方}

\footnotetext{
本稿は既往発表文献 1 ～4，6，7 に，新たな実験結果などを加筆，修正したものである。

*1 北海道立北方建築総合研究所 主任研究員 - 博士 (工学) $\quad$ Senior Research officer, Hokkaido Northern Regional Building Research Institute, Dr. Eng.

* 2 北海道立北方建贸総合研究所 研究職員. 工修

*3 近畿大学理工学部建築学科 准教授. 博士 ( 学)

*4 近重大学大学院工学研究科建筑学尃攻 准教授. 博士 (工学

* 5 的) 重本建築総合試験所試験研究セシター 室長代理

*6 東京大学大学院工学系研究科建築学専攻 教授. 㙛

Researcher, Hokkaido Northern Regional Building Research Institute, M. Eng.

Assoc. Prof., Dep. of Architecture, Faculty of Engineering, Kinki Univ., Dr. Eng

Assoc. Prof., Div. of Architecture, School of Engineering, Mie Univ., Dr. Eng.

Deputy Head, General Building Research Corporation of Japan

Prof., Div. of Architecture, School of Engineering, Tokyo Univ., Dr. Eng. 
結露・湿害の防止を目的とした断熱技術開発に関連する既往の取 組み方には大きく 2 つのアプローチがある。一つは, 各種壁体を実 物大で実験・評価し, どちらかといえば定性的な比較から壁体設計 への知見を導き出そうとする方法である。もう一つは, 実験はシミ ユレーション手法の検証と精度を高めるために行い, 壁体評価や壁 体設計の情報を数值シミュレーションで導き出そうとする方法であ る。液水現象や壁体のモデリング,物性值等に課題はあるにしても, 壁体内部の温湿度性状や構成部材の水分状態の予測に用いるシミュ レーションの実用性は高まってきており, 最近の断熱壁体開発や評 価は，どちらかといえば後者によるアプローチが多い。

いずれの場合でも, 壁体評価する際には, 前述の通り判断基準, すなわち「閾值を設定するか」を明確にすることが重要である。こ れまで防露・湿害防止上の判断に用いられる一般的な指標としては, (1)壁体内の温湿度性状・発生頻度等, (2)力ビ・木材腐朽菌注1)の生育 条件に関する既往研究例えば 1 4) などを基にした指標などのほか，(3)数 值計算で得られた木材等の構成材料の含水率経年変化から判断する 方法例えば5)などがある。しかし(2)や(3)に関しては, 既往研究で明らか となっている知見は断熱壁体内の環境条件の一部を対象としている に過ぎなく参考值として扱い, 多くは(1)をべースとしているのが現 状である。一方, 土壁住宅や RC 造建物に代表されるような竣工初期 に高含水率な構成材料を使用した建築技術, 近年の断熱壁体でも一 時的に起こり得る現象も対象に壁体構築をしていくには, 上記とは 異なる湿害防止に関するリスクコントロールの考え方が必要である。

上記の観点から, 図 1 は 3 つのリスクコントロールの考え方を概 略示したものである。

A は, 壁内での高湿化及び内部結露はいずれ木材腐朽等の生物的 劣化に結びつく危険性が高いので, 実害の防止には, Step1（壁内の 高湿化）もしくはStep2（結露の発生）を評洒指標とし，「僅かな結 露も容認しない」という考え方である。一見, この考え方は最も安 全率の高いアプローチだが, 前述の初期結露などの一時的結露現象 まで含めて考えると，現在普及展開されている様々な断熱技術を， この考え方で説明することは難しいだろう例え壮5)。仮に, 一次的結露 現象まで含めて，この考え方に基づいた壁体構築ができたとしても 多くの技術的制約条件が伴うほか, 壁体設計の自由度は現状よりも さらに制約されることになろう。

B は, 壁内が高湿になる, あるいは一時的に液水で湿潤化するこ とを容認するが, カビの発芽・生育・定着は防止するという考え方 である。カビの発生自体は, 直接躯体の耐久性にダメージを与えな いまでも, 居住空間の空気質を悪化させる危険性は高く, 湿害の一 つである。しかし, 一年のある時期, 外気条件そのものがカビの生 育条件に属するわが国の気候条件, 数千種以上にも及ぶ菌類の存在 を勘案すると, 断熱外皮設計上の闇值とするには多くの課題がある。 また, 健康害の原因となるカビの発生は, 断熱外皮技術と換気・空 調の方法や生活様式とのコンビネーションで対応寸る方がはるかに 現実的であることを考えると, 現時点で断熱外皮設計上の直接的な 評価指標とはなり得ないと考えられる。

C は, 僅かな結露は容認するが, 躯体が保有すべき物理強度への ダメージは回避するという考え方である。しかし， B と同様，断熱 外壁内におかれた木材や鉄材の劣化性状と構造性能との関係を明ら かにした既往研究は殆どなく, それを閾值とすることは難しいのが

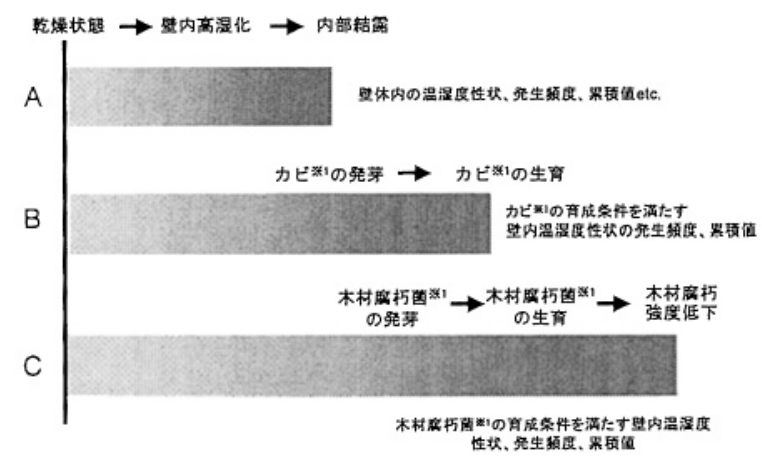

図 1 断熱壁体の湿害防止のリスクマネージメントの考え方 現状である。

いずれにしても，BやC は，「一時的な結露は容認する，建築安 全性や健康安全性に害がなければそれは容認しても構わない」とい う考え方が前提となるもので，Aに比べ壁体設計の自由度が拡大す るとともに，実情に即していることは明らかといえる。

以上の観点から，本研究では外皮技術の湿害防止のリスクコント ロールとしてCのアプローチによる劣化の数学的予測モデルを目指 すこととした。

\section{$2-2$ 実験概要}

\section{（1）実験条件}

木造建築の構造躯体内に存在する木材や木質材料は，以下のよう な環境条件下に存在していると考えられる。

(1) 床組材等のように長期間にわたって比較的安定した温湿度環境

(2) 外壁構成材や小屋組材等のように日周期で変動する温湿度環境

(3) (1)の条件下で毎日繰り返し生じる多少の結露水に晒される環境

(4) (2)の条件下で毎日繰り返し生じる多少の結露水に晒される環境

(5) 設備漏水・外部漏水等により，一時的に多量の液水に晒される 環境

上記の 5 つの環境条件を想定した実験計画の概要を表 1 に示す。 実験A 1 ～ 3 は上記(1)の環境条件, 実験 B 2, B 4, B 5 は(2), (3) 及び(4)の環境条件，実験 E 1 は(1)および(5)の環境条件を想定してい る。なお，ここで日周変動を対象としたのは定常実験との差異を明 確にするためである。周囲条件が変化することによって，定常実験 とどのような結果に違いが出るかを見ることを主目的とした。

\section{(2) 本研究で用いる劣化評価指標}

図 2 , 表 2 は, 木材重量含水率と強度の関係を概略示したもので ある。重量含水率と各種強度の一般的な関係は, 既往文献 ${ }^{7) \sim 11) ~ な と ゙ ~}$ から概ね以下のとおりに整理される。

・木材は, 重量含水率数\%から概水繊維飽和点までは含水率が低い ほど物理強度は高く, その関係は反比例関係にある。また含水率 が $1 \%$ 減少すると，表 2 に掲げる割合で強度が増加する。

・木材繊維の損傷または腐朽等がない場合は, 繊維飽和点以上では, 含有水分の多少は物理強度にほとんど影響を及ぼさず，強度は概 ね一定と考えてよい。

カビ，木材腐朽菌等の生物的要因による木材へのダメージの度合 いを，目視で判断するのは容易ではない。しかし，前述したような 含水率と物理強度の一般的な関係を参考にすれば，比較的簡単に生 物劣化の定量的な評価が可能となる。

以上から，本研究では表 2 に掲げる物理強度のうち，特に測定が 


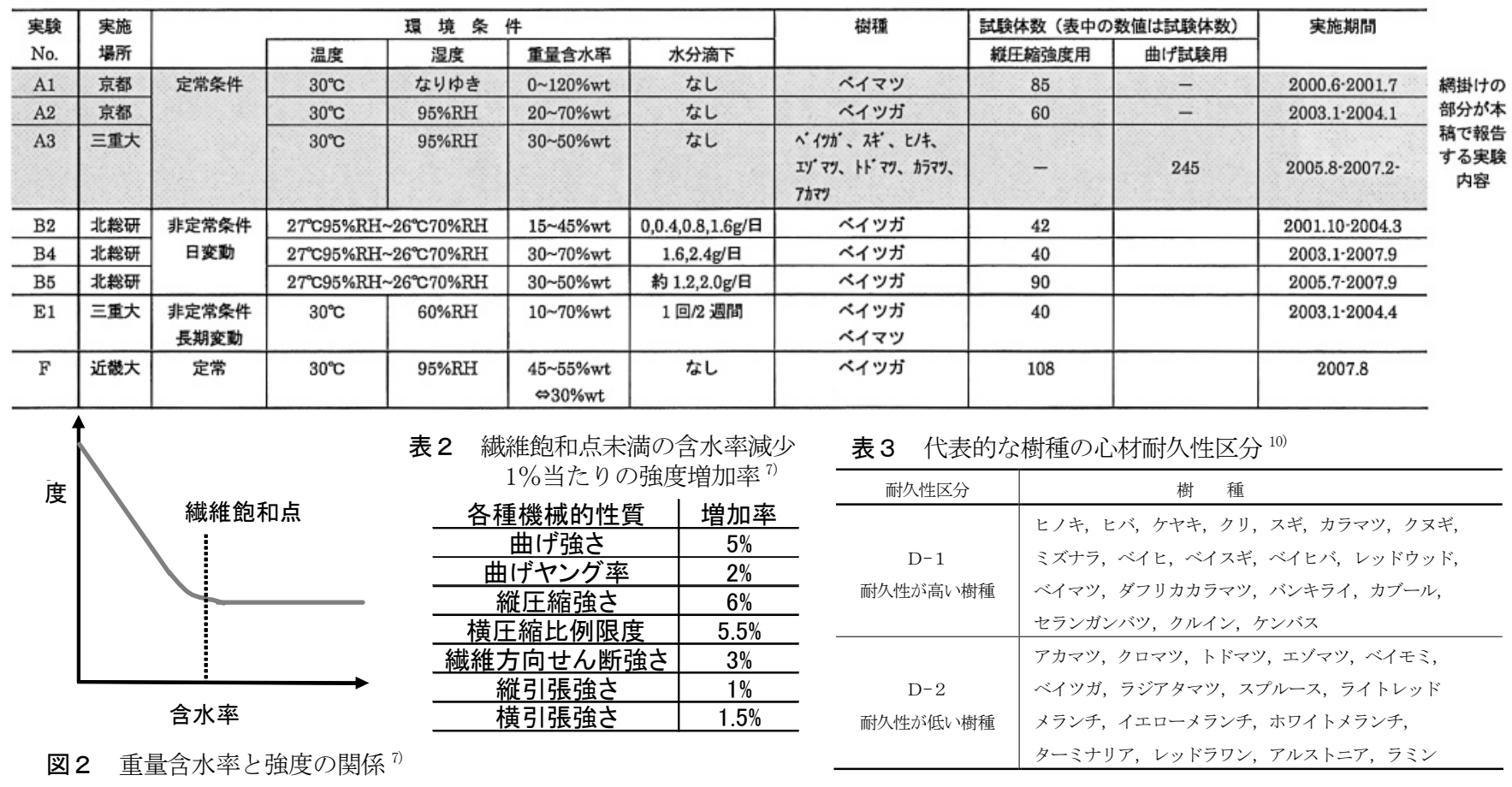

簡易で生物劣化により強度低下が生じる縦圧縮強度と試験体を破壊 することなく強度測定が可能な曲げヤング係数に着目して以下の検 討を行った。

\section{A 1 及びA 2 実験}

A 1 及びA 2 実験は, 例えば床下等, 比較的温湿度が安定した 環境下にある木材, あるいは雨水や設備漏水等の何らかの不具合等 が発生したことより高含水状態に置かれた木材の重量含水率と劣化 の関係を捉えることを主目的に実施した実験である。温湿度一定(腐 朽菌の育成可能範囲), 重量含水率を 3 段階に設定し, 先に述べた環 境条件と木材腐朽の関係をシンプルに把握することを主なねらいと している。

\section{3-1 実験概要}

\section{(1) 試験体}

試験体に用いた樹種は木造住宅の構造材として一般的なベイマ ツ辺材及びベイツガ辺材である。表 3 は各樹種の心材の耐久性区分 を示したものだが, 特にベイツガは耐久性区分 D- 2 に属し, 構造材 として用いられる木材の中では, 而久性は低い部類に属する。また, 心材に比べ辺材の耐久性は低い。従って, 実験で用いた木材は, 木 材の中でも腐朽しやすいカテゴリーに属するものといえる。試験体 寸法は $60 \mathrm{~mm} \times 50 \mathrm{~mm} \times 20 \mathrm{~mm} ，$ 木口は長辺方向にある（写真 1$)$ 。

\section{（2）実験方法}

試験体数はA $1 ，$ A 2 実験合わせて 145 個あり，試験体を絶乾状 態にした後, 表 4 示す方法によって, 重量含水率を概ね $30 \% \mathrm{wt}$ 未満, 30〜70\%wt，70\%wt 以上の 3 段階に設定した。

次に, 試験体をプラスチックケース（写真 2 ) または密閉可能な ポリエチレンフィルムケースに格納し，40\%wt 以上の試験体は 2000 年 6 月, $30 \% \mathrm{wt}$ 以下の試験体は 2000 年 9 月より室温 $30^{\circ} \mathrm{C}, \mathrm{A} 1$ 実験 では湿度なりゆきの恒温槽, A2 実験では相対湿度 95\%一定となって いる恒温恒湿室内に設置した。そして 10 週経過後から概衫 2 4 週

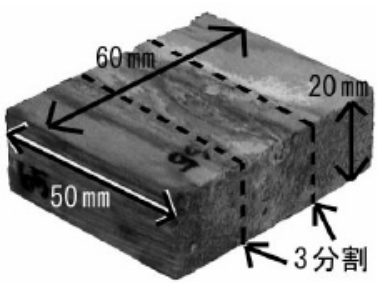

写真 1 試験体概要

表 4 実験手順（A $1 \cdot$ A 2 )

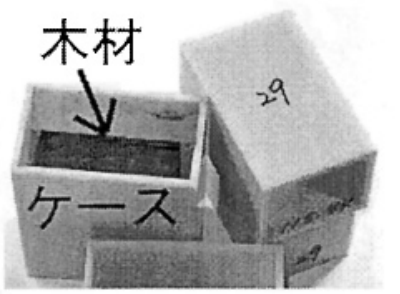

写真 2 試験体格納状況

\begin{tabular}{|c|c|c|c|}
\hline \multicolumn{2}{|r|}{ 実験手順 } & \multirow{2}{*}{\multicolumn{2}{|c|}{$\begin{array}{c}\text { 概 要 } \\
60^{\circ} \mathrm{C} \text { の状態で } 48 \text { 時間乾燥させた後に重量を測定する。 }\end{array}$}} \\
\hline (1) & 絶乾重量測定 & & \\
\hline \multirow{4}{*}{ (2) } & \multirow{4}{*}{$\begin{array}{l}\text { 試験体の } \\
\text { 重量含水率の調整 }\end{array}$} & 含水率 & 含水率調整方法 \\
\hline & & $20 \sim 30 \mathrm{wt} \%$ & $\begin{array}{l}\text { 試験体を, 純水を満たした密閉容器内に水に } \\
\text { 触れないよう設置し, 容器内の相対湿度 } 100 \% \\
\text { の空気に平衡させることで設定する } \\
\end{array}$ \\
\hline & & $30 \sim 70 \mathrm{wt} \%$ & 密閉デシケーター内で液水に試験体を浸す \\
\hline & & 80wt\%超 & $\begin{array}{l}\text { 密閉デシケーター内で液水に試験体を漬け } \\
\text { た上で, 全体を負圧にすることで吸水を促 } \\
\text { 進させる。 }\end{array}$ \\
\hline (3) & $\begin{array}{l}\text { 恒温恒湿湿 } \\
\text { に設置 }\end{array}$ & \multicolumn{2}{|c|}{$\begin{array}{l}\text { 試験体をそれぞれプラスチックケース（写真 } 2) \text { もしくはポ } \\
\text { リエチレンフィルムケースに入れる。 } \\
30^{\circ} \mathrm{C}, 95 \% \text { 一定に保った恒温室内に設置する。 }\end{array}$} \\
\hline (4) & 縦圧縮試験 & \multicolumn{2}{|c|}{$\begin{array}{l}2 \text { 週間もしくは } 1 \text { ケ月毎に試験体を取り出す。 } \\
\text { 試験体を } 3 \text { 分割（写真1）し, JISZ2101-1994 に準拠して縦圧 } \\
\text { 縮強度を測定する。 }\end{array}$} \\
\hline (5) & 絶乾重量の測定 & \multicolumn{2}{|l|}{ (1)と同じ } \\
\hline
\end{tabular}

毎に試験体を取り出し, 材料繊維方向の縦圧縮強度を測定し, 再度, 絶乾重量を測定した。なお, 実験期間中, 試験体の目標とする重量含 水率を維持するため 147 日目と 198 日目の 2 回, 恒温恒湿槽から試験 体を取り出し, 気中で試験体の重量含水率を初期值まで戻寸調整を 行なった注2)。

\section{3-2 実験結果と考察}

図 4 は, 恒温室に設置していた間の試験体の重量含水率推移を示 したものである。同じ条件で含水率調整しても，個体差の影響等に 
より, 初期的にも実験開始後も, 試験片に含水率の推移に差がみら れ, 高含水率で長期維持するのはかなり難しいことがわかる。

表 5 は実験期間中の重量含水率, 縦圧縮強度及びカビ・腐朽菌等 の目視観察結果を示したものである。図 5 は強度試験時の重量含水 率と縦圧縮強度の関係を示したものである。図中では, 縦圧縮強度 が $10\left[\mathrm{~N} / \mathrm{mm}^{2}\right]$ 以下に低下し, 木材腐朽菌が目視で確認された試験体 を点線で囲っている。また, 建築基準法で定められたベイマツの基 準強度（縦圧縮強度） $\mathrm{Fc}=18.0\left[\mathrm{~N} / \mathrm{mm}^{2}\right]^{12}$ を破線で示す。

いわゆる「健全な木材」の重量含水率と縦圧縮強度の関係は, 図 2 に示したように，一般的に $10 \sim 30 \% \mathrm{wt}$ までは直線的に変化し，そ れ以上になるとほぼ縦圧縮強度が一定となることが知られている。

表 5 及び図 5 から, 基準強度を下回った試験体は, 重量含水率が 概水 30\%wt 以上で十数週以上経過しており, 特に木材腐朽菌が確認 でき縦圧縮強度が $10\left[\mathrm{~N} / \mathrm{mm}^{2}\right]$ 以下となった 4 つの試験体は, いずれ も恒温室で 18 週（約 4 ケ月）以上経過し，この間の重量含水率が 40〜80\%wt の範囲で保たれていた試験体であることがわかる。また， カビや腐朽菌等は 10 週目以降に抽出した試験体から確認され, カビ に関しては恒温室内で重量含水率が 20\%wt 程度以上、腐朽菌は重量 含水率が 30\%wt 以上で推移していた試験体で発生していた。一方, 重量含水率が概ね 15\%wt 以下あるいは概ね 70\%wt 以上で推移してい た試験体では, 経過時間の多少に係わらずカビ・腐朽菌等が生じる 割合は少なかった。

以上のことから, 既往の木材腐朽防止の目安として一般的に知ら れている「重量含水率を $20 \%$ 以下に保つこと例玟7.8」」は必ずしも妥 当とは言えず，これよりもかなり高い重量含水率で長期間暴露され た場合に目視及び物理強度上の異常が発生するケースが殆どである ことが確認された。

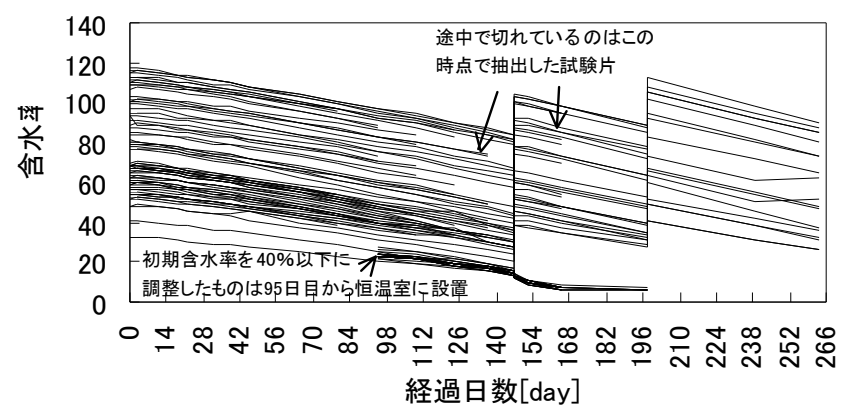

図 4 実験開始後の試験体の重量含水率変化

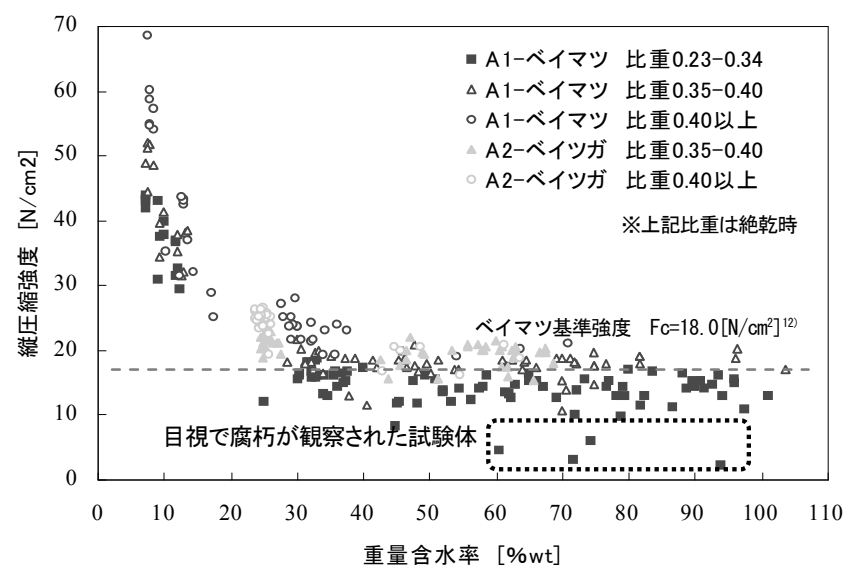

図 5 試験体の平均重量含水率と縦圧縮強度の関係
表 5 A 1 実験 各試験体の実験結果

\begin{tabular}{|c|c|c|c|c|c|c|c|c|c|c|c|}
\hline \multirow{3}{*}{$\begin{array}{l}\text { 絰 } \\
\text { 遽 }\end{array}$} & \multirow{3}{*}{$\begin{array}{l}\text { 試 } \\
\text { 験 } \\
\text { 体 } \\
\text { 䎹 }\end{array}$} & \multirow{3}{*}{ 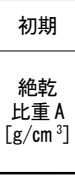 } & \multirow{3}{*}{$\begin{array}{c}\text { 恒温 } \\
\text { 恒湿室 } \\
\text { 設置 } \\
\text { 期間 } \\
\text { 今平均 } \\
\text { 含水率 } \\
{[\% \text { t }]}\end{array}$} & \multirow{3}{*}{$\begin{array}{l}\text { 抽出時 } \\
\text { 権察 } \\
\\
\text { カビの } \\
\text { 発生*1 }\end{array}$} & \multicolumn{6}{|c|}{ 試験体 3 分割後 } & \multirow{3}{*}{$\begin{array}{l}\text { 備 } \\
\text { 考 } \\
* 5\end{array}$} \\
\hline & & & & & \multicolumn{4}{|c|}{ 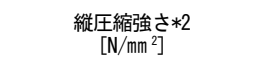 } & \multirow{2}{*}{$\begin{array}{l}\text { 䋓乾 *3 } \\
\text { 比重 } \mathrm{B} \\
{\left[\mathrm{g} / \mathrm{cm}^{3}\right]} \\
1(2) 3 \\
\text { の平均 }\end{array}$} & \multirow{2}{*}{$\begin{array}{c}\text { 比重 } \mathrm{B} \\
/ \\
\text { 比重 } \mathrm{A} \\
* 4\end{array}$} & \\
\hline & & & & & $\begin{array}{l}\text { 試験 } \\
\text { 体(1) }\end{array}$ & & & & & & \\
\hline 試 & 111 & & & & 54.6 & & & & 0. & & \\
\hline & 112 & & & & & & & & & & \\
\hline 前 & 112 & 0.39 & $\frac{-}{20}$ & & $\frac{51.6}{12.7}$ & 121 & 28 & 00 & 0.38 & \begin{tabular}{|l|}
0.97 \\
\end{tabular} & \\
\hline
\end{tabular}$$
10
$$

14

\begin{tabular}{|c|c|c|c|c|c|c|c|c|c|c|}
\hline 11 & 0.46 & 22 & 有 & 43.7 & 43.1 & 38.4 & 41.8 & 0.46 & 0.99 & \\
\hline 33 & 0.34 & 21 & 有 & 35.3 & 31.4 & 32.6 & 33.1 & 0.34 & 0.99 & \\
\hline 1 & 0.34 & 21 & 有 & 37.9 & 36.7 & 37.0 & 37.2 & 0.34 & 0.99 & \\
\hline 15 & 0.41 & 22 & 有 & 42.5 & 38.2 & 43.3 & 41.3 & 0.41 & 0.99 & \\
\hline 27 & 0.30 & 16 & 有 & 43.2 & 37.6 & 28.1 & 36.3 & 0.29 & 0.98
\end{tabular}

\begin{tabular}{|c|c|c|c|c|c|c|c|c|c|c|}
\hline 27 & & & & & & & & & & \\
\hline$\frac{21}{13}$ & $\begin{array}{l}0.30 \\
0.38\end{array}$ & $\begin{array}{l}16 \\
16\end{array}$ & 量 & \begin{tabular}{|l|}
3.2 .2 \\
3.5
\end{tabular} & 31.0 & 28.1 & $\frac{30.5}{34.5}$ & $\frac{0.29}{0.37}$ & \begin{tabular}{|l|l}
0.98 \\
100
\end{tabular} & ※ \\
\hline 0 & 0.35 & 16 & 有 & 37.9 & 41.4 & 39.8 & 39.7 & 0.34 & 0.99 & \\
\hline 20 & 035 & 16 & 有 & 396 & & & 396 & 035 & 100 & ※ \\
\hline 98 & 0.41 & 53 & 有 & 20.9 & & 23.6 & 22.6 & 0.41 & 0 & \\
\hline \begin{tabular}{|l}
52 \\
\end{tabular} & 0.45 & 52 & 肴 & 16.8 & 19.4 & 21.3 & 19.2 & 0.43 & \begin{tabular}{|l}
0.96 \\
\end{tabular} & \\
\hline
\end{tabular}

(1)

\begin{tabular}{|c|c|c|c|c|c|c|c|c|c|c|c|}
\hline & & & & & & & & & & & \\
\hline & 73 & 0.39 & 61 & 罠 & 20.0 & 18.0 & 18.4 & 18.8 & 0.38 & 0.99 & \\
\hline & 79 & 0.37 & 89 & 有 & \begin{tabular}{|l|l}
18.4 \\
\end{tabular} & 17.7 & 18.2 & 18.1 & 0.36 & 0.98 & \\
\hline & 80 & 0.31 & 106 & & 14.2 & 15.1 & 15.3 & 14.9 & 0.30 & 0.98 & \\
\hline & 88 & 0.35 & 86 & 有 & \begin{tabular}{|l|}
13.8 \\
\end{tabular} & 13.9 & 15.7 & 14.5 & 0.35 & 0.98 & \\
\hline & 96 & 0.33 & 105 & 有 & 15.6 & 15.4 & \begin{tabular}{|l|}
16.3 \\
\end{tabular} & 15.8 & 0.32 & 0.98 & \\
\hline & 60 & 0.36 & 51 & 有 & \begin{tabular}{|l|}
17.9 \\
\end{tabular} & 17.0 & 18.8 & 17.9 & 0.36 & 0.99 & \\
\hline \multirow{7}{*}{1} & 45 & 0.36 & 59 & 有 & $\begin{array}{l}18.2 \\
\end{array}$ & 17.3 & \begin{tabular}{|l|}
16.5 \\
\end{tabular} & 17.3 & 0.35 & 0.98 & \\
\hline & 38 & 0.35 & 56 & 有 & 16.8 & 15.1 & 16.4 & 16.1 & 0.34 & 0.98 & \\
\hline & 43 & 0.35 & 47 & 有 & \begin{tabular}{|l|}
18.1 \\
\end{tabular} & 16.1 & \begin{tabular}{|l|}
16.7 \\
\end{tabular} & 17.0 & 0.35 & 0.98 & \\
\hline & 78 & 0.35 & 97 & 有 & 16.4 & 16.8 & 16.9 & 16.7 & 0.34 & 0.98 & \\
\hline & 99 & 0.41 & 100 & 罠 & 20.3 & 19.2 & $\begin{array}{l}17.2 \\
\end{array}$ & 18.9 & 0.40 & 0.98 & \\
\hline & 89 & 0.37 & 80 & 肙 & 17.0 & 18.3 & \begin{tabular}{|l|}
17.1 \\
\end{tabular} & 17.5 & 0.37 & 0.98 & \\
\hline & 85 & 0.40 & 83 & 畊 & 19.7 & 21.1 & \begin{tabular}{|l|}
18.7 \\
\end{tabular} & 19.8 & 0.39 & 0.98 & \\
\hline \multirow{8}{*}{18} & 91 & 0.44 & 46 & 有 & \begin{tabular}{|l|}
24.1 \\
\end{tabular} & 24.2 & \begin{tabular}{|l|}
23.7 \\
\end{tabular} & 24.0 & 0.44 & 0.97 & \\
\hline & 64 & 0.42 & 45 & 有 & \begin{tabular}{|l|}
20.7 \\
\end{tabular} & 21.6 & \begin{tabular}{|l|l|}
21.6 \\
\end{tabular} & 21.3 & 0.42 & 0.97 & \\
\hline & 67 & 0.38 & 57 & 腐朽菌 & 6.2 & 4.7 & \begin{tabular}{|l|}
11.7 \\
\end{tabular} & 7.5 & 0.33 & 0.85 & \\
\hline & 58 & 0.30 & 55 & 有 & 15.3 & 16.3 & 16.2 & 15.9 & 0.30 & 0.97 & \\
\hline & 68 & 0.34 & 71 & 䈐 & \begin{tabular}{|l|}
14.5 \\
\end{tabular} & 12.2 & \begin{tabular}{|l|}
12.7 \\
\end{tabular} & 13.1 & 0.34 & 0.97 & \\
\hline & 100 & 0.38 & 76 & & 18.4 & 18.4 & 18.4 & 18.4 & 0.37 & 0.97 & \\
\hline & 83 & 0.35 & 104 & 有 & 16.1 & 15.7 & 15.5 & 15.8 & 0.34 & 0.97 & \\
\hline & 81 & 0.31 & 103 & & \begin{tabular}{|l|l|}
14.7 \\
\end{tabular} & 14.4 & 15.4 & 14.8 & 0.30 & 0.97 & \\
\hline \multirow{8}{*}{20} & 97 & 0.49 & 46 & 有 & 27.1 & 24.1 & 23.2 & 24.8 & 0.48 & 0.97 & \\
\hline & 93 & 0.45 & 45 & 有 & 25.2 & 25.2 & \begin{tabular}{|l|l|}
28.1 \\
\end{tabular} & 26.1 & 0.45 & 0.97 & \\
\hline & 37 & 0.36 & 55 & 有 & 18.4 & 19.6 & 18.9 & 19.0 & 0.35 & 0.97 & \\
\hline & 56 & 0.35 & 57 & 䈐 & 18.2 & 16.7 & 11.9 & 15.6 & 0.34 & 0.96 & \\
\hline & 70 & 0.32 & 67 & 有 & \begin{tabular}{|l|}
12.7 \\
\end{tabular} & 11.7 & 13.4 & 12.6 & 0.32 & 0.96 & \\
\hline & 72 & 0.31 & 68 & 肙 & 15.8 & 15.3 & 14.2 & 15.1 & 0.30 & 0.97 & \\
\hline & 107 & 0.36 & 91 & & 16.2 & 17.8 & \begin{tabular}{|l|}
18.7 \\
\end{tabular} & 17.6 & 0.36 & 0.97 & \\
\hline & 94 & 0.36 & 92 & 有 & 17.6 & 17.7 & \begin{tabular}{|l|}
17.8 \\
\end{tabular} & 17.7 & 0.36 & 0.97 & \\
\hline \multirow{12}{*}{24} & 29 & 0.35 & 12 & & & & & & 0.35 & 0.99 & ※ \\
\hline & 2 & 0.35 & 12 & & 44.6 & 49.0 & \begin{tabular}{|l|}
44.1 \\
\end{tabular} & 45.9 & 0.35 & 1.00 & \\
\hline & 36 & 0.41 & 13 & 有 & 51.3 & 52.2 & 54.8 & 52.8 & 0.41 & 0.99 & \\
\hline & 19 & 0.33 & 12 & & 43.3 & 43.1 & 42.0 & 42.8 & 0.33 & 0.98 & \\
\hline & 40 & 0.36 & 49 & 腐朽菌 & 19.1 & 13.5 & 16.2 & 16.3 & 0.34 & 0.95 & \\
\hline & 57 & 0.39 & 53 & 有 & $\begin{array}{l}19.1 \\
\end{array}$ & 19.9 & \begin{tabular}{|l|}
18.6 \\
\end{tabular} & 19.2 & 0.39 & 0.99 & \\
\hline & 39 & 0.36 & 57 & 腐朽菌 & 2.2 & 3.1 & 3.8 & 3.0 & 0.27 & 0.74 & \\
\hline & 46 & 0.35 & 63 & 腐朽菌 & 10.0 & 10.1 & \begin{tabular}{|l|}
1.1 \\
\end{tabular} & 10.4 & 0.31 & 0.88 & \\
\hline & 106 & 0.38 & 88 & & 18.0 & 19.2 & \begin{tabular}{|l|}
18.7 \\
\end{tabular} & 18.6 & 0.37 & 0.98 & \\
\hline & 108 & 0.38 & 107 & & 18.8 & 18.8 & 20.2 & 19.3 & 0.37 & 0.98 & \\
\hline & 76 & 0.32 & 107 & & 14.2 & 12.9 & 13.0 & 13.4 & 0.32 & 0.98 & \\
\hline & 75 & 0.35 & 84 & & 14.4 & 14.5 & 14.8 & 14.6 & 0.34 & 0.97 & \\
\hline \multirow{8}{*}{28} & 49 & 0.39 & 37 & 腐朽菌 & 18.3 & 20.2 & \begin{tabular}{|l|}
21.7 \\
\end{tabular} & 20.1 & 0.39 & 0.99 & \\
\hline & 82 & 0.46 & 39 & 有 & 23.8 & & & 23.8 & 0.46 & 0.99 & ※ \\
\hline & 59 & 0.36 & 46 & 腐朽菌 & 17.5 & 18.3 & 15.5 & 17.1 & 0.34 & 0.96 & \\
\hline & 51 & 0.36 & 51 & 腐朽菌 & 16.5 & & & 16.5 & 0.36 & 0.98 & ※ \\
\hline & 54 & 0.32 & 65 & & 12.9 & 13.2 & 13.1 & 13.1 & 0.31 & 0.98 & \\
\hline & 71 & 0.30 & 64 & & 14. 2 & & & 14. 2 & 0.30 & 0.99 & ※ \\
\hline & 74 & 0.30 & 81 & & 13.7 & 14.4 & 14.3 & 14.1 & 0.29 & 0.98 & \\
\hline & 102 & 0.38 & 85 & & 14.6 & & & 14.6 & 0.37 & 0.99 & ※ \\
\hline \multirow{8}{*}{38} & 65 & 0.44 & 54 & 腐朽菌 & 10.8 & & & 10.8 & 0.37 & 0.84 & $※$ \\
\hline & 47 & 0.36 & 60 & 腐朽菌 & 12.3 & 11.2 & 10.5 & 11.3 & 0.33 & 0.92 & \\
\hline & 104 & 0.41 & 55 & ? & 19.3 & & & 19.3 & 0.40 & 0.98 & ※ \\
\hline & 66 & 0.30 & 54 & $?$ & 16.6 & 15.9 & $\mid 16.1$ & 16.2 & 0.30 & 0.97 & \\
\hline & 53 & 0.35 & 82 & 腐朽菌 & 5.8 & & & 5.8 & 0.28 & 0.81 & ※ \\
\hline & 69 & 0.36 & 118 & $?$ & 15.2 & 17.2 & 18.8 & 17.1 & 0.35 & 0.98 & \\
\hline & 87 & 0.34 & 105 & $?$ & 13.0 & & & 13.0 & 0.33 & 0.99 & ※ \\
\hline & 84 & 0.33 & 106 & $?$ & 11.4 & 12.9 & 12.5 & 12.3 & 0.33 & 0.98 & \\
\hline & 18 & 0.41 & 13 & & 31.7 & & & 31.7 & 0.48 & 1.02 & ※ \\
\hline 40 & 22 & 0.41 & 12 & & 35.2 & & & 35.2 & 0.41 & 0.99 & ※ \\
\hline 40 & 23 & 0.32 & 12 & & 29.6 & & & 29.6 & 0.33 & 1.01 & $※$ \\
\hline & 34 & 0.34 & 12 & 有 & 30.9 & & & 30.9 & 0.34 & 1.01 & ※ \\
\hline & 42 & 0.35 & 49 & 腐朽菌 & 12.2 & & & 12.2 & 0.33 & 0.95 & ※ \\
\hline & 44 & 0.37 & 54 & 腐朽菌 & 13.0 & & & 13.0 & 0.36 & 0.98 & ※ \\
\hline & 50 & 0.47 & 27 & $?$ & 32.2 & & & 32.2 & 0.47 & 1.00 & $※$ \\
\hline & 61 & 0.37 & 48 & 腐朽菌 & 8.4 & & & 8.4 & 0.32 & 0.86 & ※ \\
\hline & 62 & 0.41 & 32 & $?$ & 25.3 & & & 25.3 & 0.42 & 1.00 & ※ \\
\hline 54 & 86 & 0.49 & 32 & $?$ & 37.1 & & & 37.1 & 0.49 & 1.00 & ※ \\
\hline & 103 & 0.44 & 41 & $?$ & 29.0 & & & 29.0 & 0.44 & 1.00 & ※ \\
\hline & 77 & 0.31 & 90 & & 13.8 & & & 13.8 & 0.31 & 1.00 & $※$ \\
\hline & 95 & 0.34 & 95 & & 15.2 & & & 15.2 & 0.34 & 1.00 & $※$ \\
\hline & 101 & 0.38 & 79 & & 17.2 & & & 17.2 & 0.38 & 1.00 & $※$ \\
\hline
\end{tabular}

*1 カビ, 腐朽菌の判定は (独) 森林総研鈴木憲太郎氏による目視調査により行なった。腐朽 菌は主に白色腐朽菌と推定される。?はカビか腐朽菌か特定できないが何らかの異常が観察 された試験体、また空欄は目視ではカビや腐朽菌の発生が確認できなかった試験体を示す。 $* 2$ 縦圧縮強さの空欄部は欠測を示寸。 *3 絶乾比重 B は縦圧縮強度測定実施直後に測定し た。4 比重 B は圧縮試験実施後，比較的立方体形状に保たれていた試験片の体積・質量 から求めたものであり，測定精度にばらつきがあるため参考值とする。

*5 備考欄※は 3 分割せずに圧縮強度を計測した試験体を示す。空欄の試験体は写真 1 に示す とおり 3 分割した後, 各部分の強度を測定した。 


\section{A 3 実験}

A 3 実験は, A 1 ・A 2 実験の温湿度環境状態を基本にした日周 変動を想定した周期的定常条件下における実験である。A 1, A 2 実験は劣化の評価指標に縦圧縮強度を用いたが, 縦圧縮強度の測定 は破壊試験であることから，同一材種の個体差の判断は容易ではな い。また，恒温室容積の関係から同時に養生できる試験体数に限り があるため, 材種はベイマツ, ベイツガの 2 種類に限定していた。 そこで, A 3 実験では, 非破壊での強度確認が可能な曲げヤング係 数を腐朽判断指標とする小断面の試験体をも作成し, 合計 7 種類の 樹種を対象に実験を行った。

\section{4-1 実験概要}

\section{（1）試験体（表 1)}

試験体に用いた樹種はA 1, A 2 実験のベイツガ辺材に加えアカ マツ, エゾマツ, カラマツ, スギ, トドマツ, ヒノキの 7 種とした。 試験体寸法は $2 \mathrm{~mm} \times 12 \mathrm{~mm} \times 50 \mathrm{~mm}$, 試験体数は 245 個（35 個 $\times 7$ 樹種 $)$ である。各材種 35 個の試験体のうち 10 個は両端（木口面）をエポ キシ樹脂のシールで断湿している(以下，シールありと称す)。これ は木口面から腐朽菌の進入が起こる可能性を考慮し, 両端シールな しの場合と比較するためである。

\section{（2）実験方法}

A 1, A 2 実験同様に, 絶乾重量を測定した後, 表 6 に示す方法 によって重量含水率を概ね 30\%wt〜 70\%wt 設定した。試験体は材種 毎にステンレスレイに並べ (写真 3 ), 室温 $30^{\circ} \mathrm{C}$, 相対湿度 $95 \%$ 一定 の恒温恒湿室内に設置した。そして 1 ケ月あるいは 2 ケ月毎に全試 験体を取り出し, 日本建築総合試験所（大阪府吹田市）に輸送し, 曲げヤング係数及び重量含水率を測定した。

木材試験体の含水率は, 週末，祝日等を除く平日に毎日一回，霧 吹きにて純水を数回噴霧することにより調整した。なお，全実験期 間に対する含水率調整日の割合は 6〜 7 程度である。

図 6 に, 霧吹き給水前後のベイツガ試験体含水率測定結果の一例 を示す。本実験試験体は薄板形状であり, 24 時間毎の給水であって も, 図に示寸ように 24 時間後には設定含水率の $30 \%$ wt を下回るこ とから (20\%wt を下回ることはない), 含水率調整を行う平日におい ても 4,5 時間程度は設定含水率を下回る。以上のことから, A 3 実 験における設定含水率維持時間は, 全実験時間の約 5 割程度の時間 であると推察される。

A 3 実験では, 写真 4 に示すような曲げ強度実験から求めたヤン グ係数と試験時の重量含水率の関係から考察する。含水率の算出式 は, 以下の通りである。ただし, シールありの試験体については, シールの重量を含むため, 算出式は以下の通りになる。

$$
\begin{aligned}
\Psi= & \frac{\omega-\omega_{1}}{\omega_{0}} \\
\text { ここで, } & \phi: \text { 重量含水率 }[\%] \\
& \omega: \text { 試験体の重量 }[\mathrm{g}] \\
& \omega_{0}: \text { 試験体の絶乾重量 (シールなし) }[\mathrm{g}] \\
& \omega_{1}: \text { 試験体の絶乾重量 (シール含む) }[\mathrm{g}]
\end{aligned}
$$

\begin{tabular}{|c|c|c|c|}
\hline \multicolumn{2}{|r|}{ 手 順 } & \multirow{2}{*}{\multicolumn{2}{|c|}{$\begin{array}{c}\text { 手 法 } \\
60^{\circ} \mathrm{C} \text { の状態で } 48 \text { 時間乾燥させた後に重量を測定する。 }\end{array}$}} \\
\hline (1) & 絶乾重量測定 & & \\
\hline \multirow[b]{2}{*}{ (2) } & \multirow{2}{*}{$\begin{array}{l}\text { 試験体の } \\
\text { 重量含水率の調整 }\end{array}$} & 含水率 & 含水率調整方法 \\
\hline & & $30 \sim 70 \mathrm{wt} \%$ & $\begin{array}{l}\text { 試験体をステンレストレイに並べ，一日に一度， } \\
\text { 純水を霧吹きにて噴霧する。 }\end{array}$ \\
\hline (3) & $\begin{array}{l}\text { 恒温恒湿湿 } \\
\text { に設置 }\end{array}$ & $\begin{array}{l}\text { ステンレス } \\
\text { 設置する }\end{array}$ & $\begin{array}{l}\text { レイに並ベて, } 30^{\circ} \mathrm{C}, 95 \% \text { 一定に保った恒温室内に } \\
\text { 真3)。 }\end{array}$ \\
\hline (4) & 縦圧縮試験 & $\begin{array}{l}1 \text { ケ月もし } \\
\text { 験所に輸送 } \\
\text { 4)。曲げ試 }\end{array}$ & $\begin{array}{l}\text { よ2 ヶ月毎に全試験体を取り出し, 日本建築総合試 } \\
\text { 含水率測定および曲げ強度試験を実施する（写真 } \\
\text { さJISZ2101-1994に準拠し実施。 }\end{array}$ \\
\hline (5) & 含水率の測定 & 一週間に一 & 重量含水率を測定する。 \\
\hline
\end{tabular}

また，ヤング係数は次式で算出する。

$$
E=\frac{\Delta P L^{3}}{48 I \Delta y}
$$

表 6 実験手順（A 3 実験）
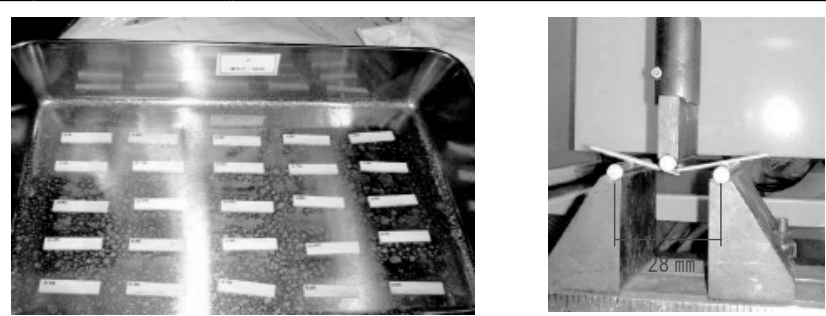

写真 3 A 3 実験の試験体設置状況 写真 4 曲げ試験実施状況

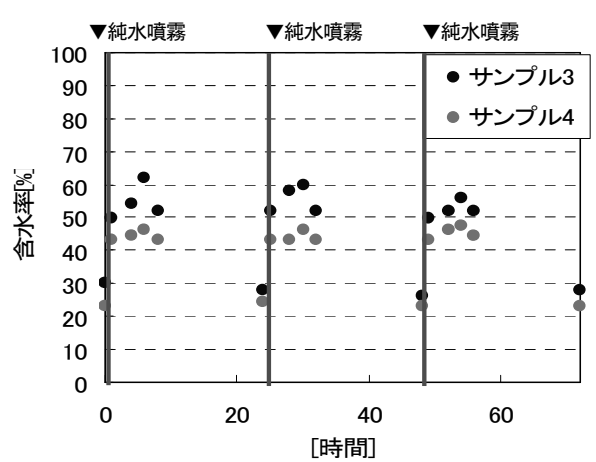

図 6 曲げ試験用試験体の重量含水率の日変動例

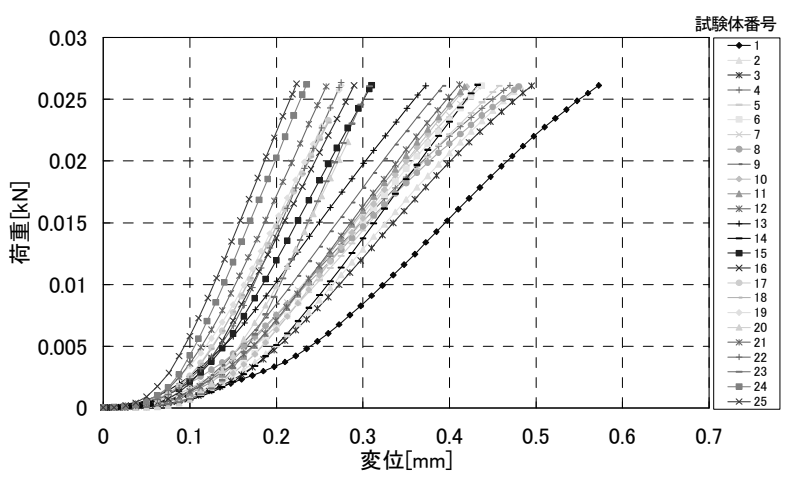

図 7 スギの曲げ試験結果の一例（変異一荷重関係）

ここで， $\Delta \mathrm{P}$ ：比例域における上限荷重と下限荷重との差 $[\mathrm{kN}]$

$\mathrm{L}:$ 支点間距離 $[\mathrm{cm}](=2.8 \mathrm{~cm})$

$\Delta \mathrm{y}: \Delta \mathrm{P}$ に対するスパン中央のたわみ $[\mathrm{cm}]$

$\mathrm{I}$ : 断面 2 次モーメント $\left[\mathrm{cm}^{4}\right] \quad\left(0.0008 \mathrm{~cm}^{4}\right)$

Lの支点間距離とは実験機器で設定された支点間距離を指し, 本 実験では $2.8 \mathrm{~cm}$ と設定した (写真 4 )。荷重面は, 保存時に上部とな る面に統一し, 荷重は試験体の中央にかける。載荷速度は $1 \mathrm{~mm} / \mathrm{s}$ で, 荷重は $0.025 \mathrm{kN}$ (これは事前の曲げの破壊試験によって得られた破 壊荷重の $2 / 3$ 程度から決定したものである）とした。図 7 のスギに おける荷重・変位関係に示す例のように, $\Delta \mathrm{P}$ は, おおよその比例 域を決定し, その区間の上限荷重と下限荷重との差によって求めた。 


\section{4-2Ａ３実験の結果と考察}

曲げ強度実験は実験開始の 2005 年 8 月から 2006 年 12 月までの期 間で合計 9 回実施した。第 1 回目は 2005 年 10 月 12 日（実験開始 2 ケ月， 11 週目)，第 2 回目 2005 年 11 月 17 日 (実験開始 3 ケ月, 16 週目), 第 3 回目 2005 年 12 月 14 日 (実験開始 4 ヶ月, 20 週目) 以降 は 2 ケ月に一度実施した。但し，3 回目の実験に関しては，実験途 中に試験機が故障したため，ヒノキ，スギシールなし，エゾマツシ 一ルなしの一部しか行えなかった。また，第一回目の 2005 年 10 月 の含水率測定は一部の試験体のみしか計測できていない。

図 8 に全 7 材種の各試験体ヤング係数の変化率及び各材種の平均 変化率を示す。なお，曲げ試験は三重から大阪に輸送し実施してお り, 試験時毎に試験体の含水率が異なること（15～25\%wt 程度）や 各試験体の個体差を考慮し, 第 2 回（実験開始 2 力月後, 2005 年 11 月）の各試験体ヤ ング係数を基準とし, 表 2 に 示寸含水率補正後の変化率を 示している。また, 両端をシ ールした試験体とシール無し の試験体には特に差異がなか ったため, ここでは, シール 無しの試験体の結果を示した。

図に示すように，ヒノキを 除く全ての材種で実験開始 8 ヶ月後（35 週，2006 年 4 月） には平均ヤング係数が基準の 実験開始 3 ヶ月後（16 週）の 值加 10\%以上（11～22\%） 低下している。ヒノキについ ては, 実験開始 8 ケ月後の平 均のヤング係数低下率は $4 \%$ 程度であったが，それ以前の 変化率が逆に $8 \%$ 程度増加し ており, 直前の值からの低下 率では, 他の材種と同程度で あった。なお，実験開始 10 ケ月後には目視による観察で も一部腐朽が確認されている。 本実験試験体は極めて小さな 試験体であり，その測定誤差 や曲げ試験実施間隔が 2 ケ月 に一度程度であること等を考 慮すれば，強度低下による腐 朽開始時期を明確に判断する ことは困難であるが，上記の 考察から, 全ての材種におい て実験開始 8 ケ月〜 10 ケ月後 程度の間に腐朽が始まったと 判断してよかろう。

曲げ試験によるヤング係数
を腐朽判断指標としたA 3 実験の結果は先のA 1 , A 2 実験の結果 と比較すると腐朽あるいは強度低下の開始がかなり遅くなっている が，先に述べたように，A 3 実験全期間中で含水率が 30\%wt 以上に 維持されている期間が, 全期間の半分程度であることを考慮すると, 全ての材種において 30\%wt 以上 となっている累積時間が 17〜26 週程度間で強度低下が開始していることになり概初A 1 ・A 2 実験 の期間と一致する。このことは, 大略 20〜30\%wt の含水状態の期間 は強度低下等に現れる腐朽の進行は生じない期間であるという可能 性を示していると言えよう。

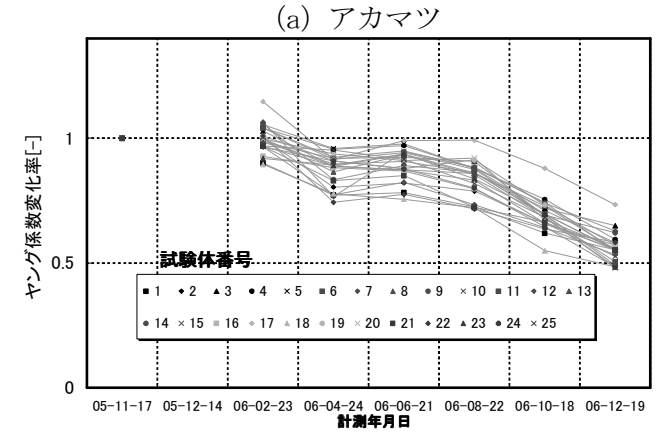

(c) カラマ

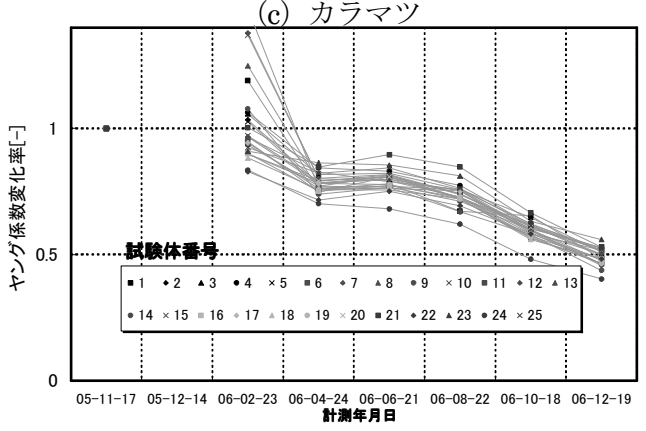

(e) ベイツガ

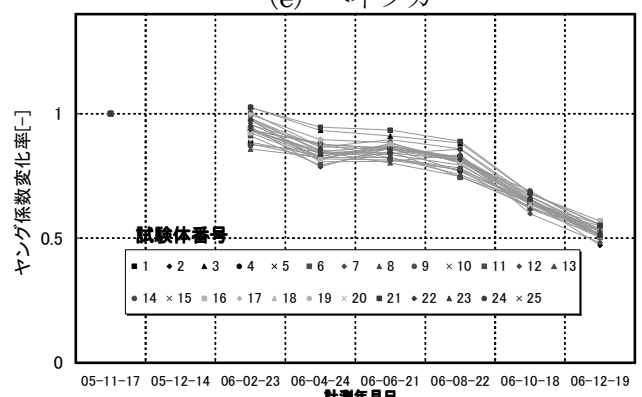

(g) ヒノキ

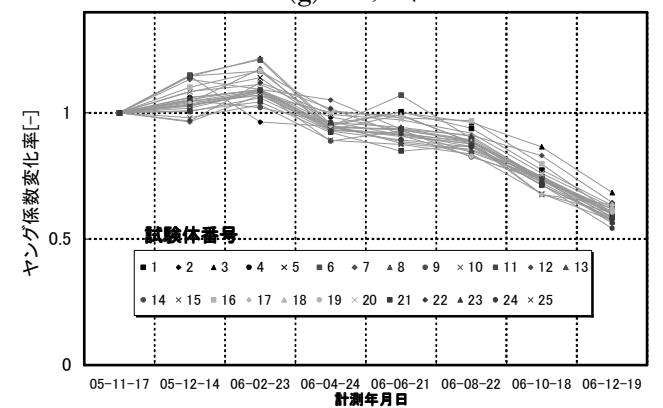

(b) エゾマツ

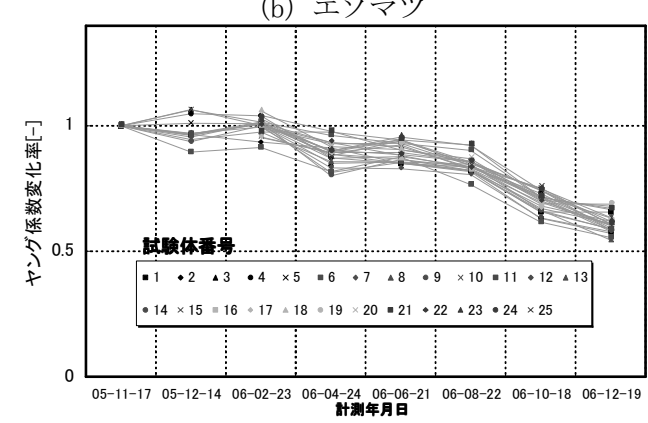

(d) スギ

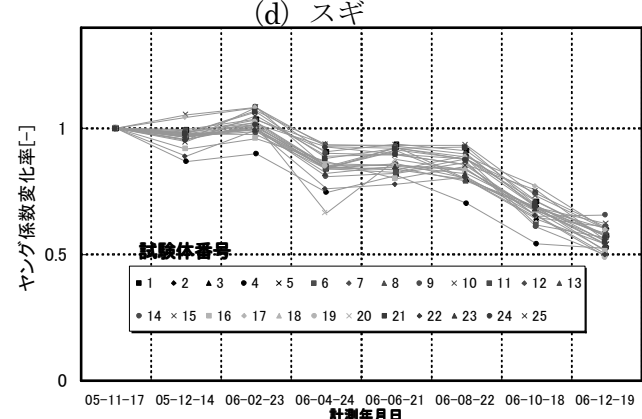

(f) トドマツ

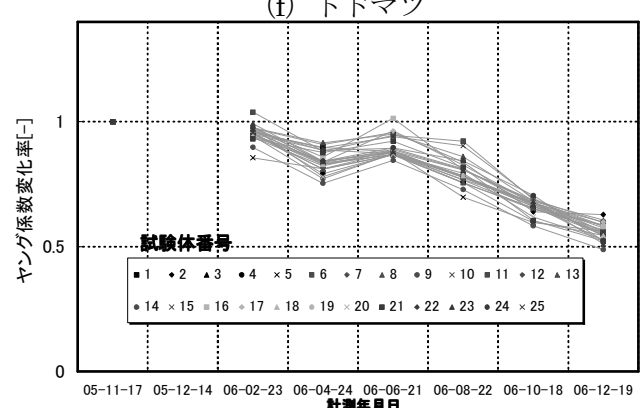

(h) 各樹種別平均值

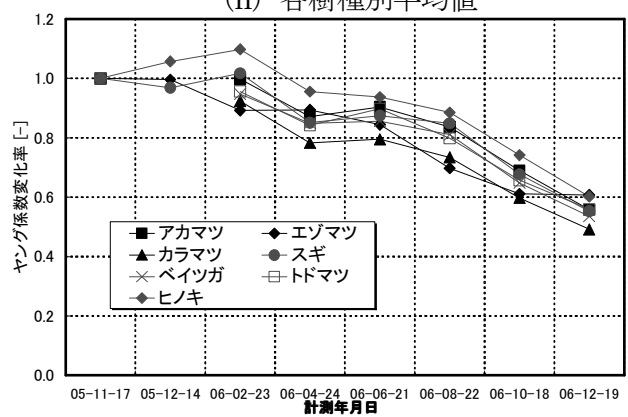

図 8 ヤング係数変化率化率 


\section{5. まとめ}

本報告では，2で述べたような湿害防止のための評価指標開発を 目的として, 建築に用いられる木材の中からからべイツガを始めと する様々な汎用樹種を対象に, 雰囲気の温湿度や試験体含水率を一 定範囲に維持する定常条件下において実験的検討を行った。

本報で得られた主な知見をまとめると以下の通りである。

（1）ベイツガ・ベイマツを試験体に用いたA 1 ・A 2 実験から, 特 定の含水率範囲で一定の時間経過と共に腐朽菌の生育が確認 され, 縦圧縮強度の低下が生じた。重量含水率は 30〜 70\%wt, 経過時間は約 16 週から 18 週の間と推測される。この含水率域 は従来言われている腐朽の目安となる含水率よりも高い。

（2）薄板試験体を用いたA 3 実験から， 7 樹種全てのヤング係数が， 実験開始後 35 週程度から低下が始まった。これは，（1）の結 果に比して倍程度の期間であるが，本実験における試験体の $30 \% \mathrm{wt}$ 70\%wt 維持時間は概ね全実験期間の半分程度であるこ とから，含水率 $30 \% \mathrm{wt}$ 未満の期間を除けば，上記（1）の期間 と概数一致すると考えられる。

（3）（2）の結果から，20～30\%wt の含水状態の期間は強度低下等 に現れる腐朽の進行に寄与しない可能性がある。また、変動す る条件下で腐朽が観察されたことは今後の腐朽条件の更なる明 確化に対して大きな意味を持つと考えられる。

本報で示した実験結果から得られた知見は，これまでの“木材腐 朽”の発生条件に関する知見とは異なるものといえる。その違いを 概念的に示寸と図 9 のようになる。図（a）は，これまでの考え方を 示したもので，重量含水率が一定レベル（20～30\% w t ）以上に保 たれ，ある一定温度以上になると，時間軸には関係なく木材は腐朽 する危険性が高いというものである。一方，本報により得られた知 見は, 図（b）に示すように木材腐朽は重量含水率と環境条件（図 では経過時間のみ示寸) に大きく左右されるという結果となってい る。定量的かつ実用的なダメージの数学的予測モデルを構築してい くには，ダメージを受けない条件 (図bでは【白】と記した部分), ダメージを受ける条件（図bでは【黒】と記した部分）に関して再 検証を目的とした実験を行いより信頼性の高いデータを得るととも に，まだ明らかとなっていないグレーゾーンを明らかにする必要が ある。また同様の考え方に基づき, 外壁内部等の温湿度変化の大き な環境条件（非定常）を想定した実験も進めていく必要がある。

なお，本実験から得られた知見は，未だ限定した実験条件から得 られたものであり, 現時点では実建物の木材腐朽の判断・予測に適

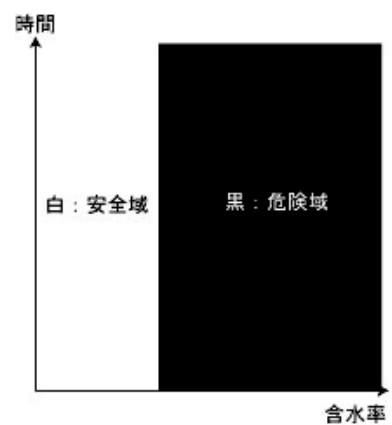

(a) 既往の考え方

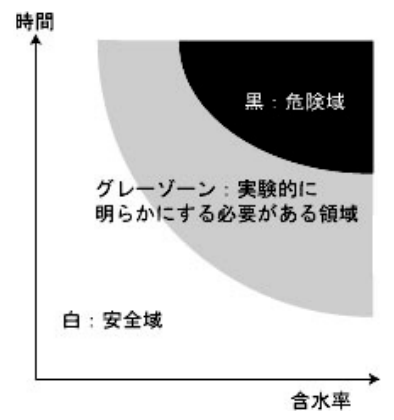

（b）本報で得られたイメージ
図 9 木材の湿害危険域の概念
用されるべきではないと考えている。今後は，実建物における観察 結果等を参照し、数量的な表現に関する調整を行う必要がある。ま た，上記の関連から既にいくつかの実験・分析が進行中であり，そ れらの検討結果については，次報にて報告する所存である。

\section{謝 辞}

本研究グループのメンバーであった故・鈴木憲太郎先生（森林総合研 究所）には有益なご意見を多数頂いた。ここに記して深甚の謝意を表す ると共にご冥福をお祈りしたい。また，本実験遂行およびデータ整理に あたり, 三重大学工学部建築学科環境系研究室および近畿大学理工学部 建築学科環境系研究室の大学院生・学部生に多大な協力を頂いた。ここ に記して謝意を表する。なお，本研究の一部は平成 16 年度〜平成 18 年度科学研究費補助金・基盤研究（B）（1）(課題番号 : 16360286, 研究 代表者 : 坂本雄三）による。

注

注 1)木材に付着・生育する菌として主に表層で発生し木材の強度等には重大な影響が 及ばないものと, 木材に含まれるリグニン・セルロース・ヘミセルロースなどを積極的に 分解して物理強度の低下や比重・質量変化をもたらすものがある。本稿では一般的な 呼称にならい前者をカビ，耐久上の支障をもたらす後者を木材腐朽菌と称している。

注 2）実験当初は恒温恒湿槽内の相対湿度を $100 \%$ RH $の$ 状態に維持寸ることを意図 したが, 恒温恒湿槽の制御機構の問題から安定維持できる相対湿度は $95 \%$ RH であ ったため, 試験片の含水率調整を人為的に行なうこととした。また既往の研究で用い られる密閉容器で含水率を維持する方法は, 初期の空気成分の及ぼす影響が高まり, 特定菌のみを対象とした実験結果となり, 研究の目的に即さない危険性も考えられた ため, 試験片を密閉容器内で養生する方法は採らなかった。

\section{本論文に関連する主な既往発表文献}

1 鈴木大隆，岩前篤，永井久也，本間義規，北谷幸恵ほか：2つの環境条件下に おいて生物的要因が木材の物理的性能に与える影響-主に断熱壁体の内部温湿度 環境と湿害の観点から-, 日本建築学会環境工学委員会 熱環境小委員会第 31 回 熱シンポジウム「湿気研究の新たなる進展」梗概集, pp41-46,2001.10

2 北谷幸恵, 鈴木大隆, 岩前篤, 鈴木憲太郎ほか：いくつかの環境条件下における 生物的要因が木材の物理的性能に与える影響（その 1) 定常条件に置かれた木 材の含水率と腐朽の関係, 日本建築学会大会学術講演集 D-2, PP.279-280, 2001

3 鈴木大隆, 北谷幸恵, 岩前篤, 鈴木憲太郎, 永井久也, 近田智也ほか, 同名論文 (その 2) 非定常条件に置かれた木材の含水率と腐朽の関係，日本建築学会大会学 術講演集 D-2，PP.277-278，2002

4 鈴木大隆, 北谷幸恵, 永井久也,梅野徹也,岩前篤, 鈴木憲太郎ほか, 同名論文（そ の 3) 各種条件下に置かれた木材の腐朽, 日本建築学会大会学術講演集 D-2, PP.491-492, 2004

5 鈴木大隆; 寒冷地における断熱外皮の技術動向と今後の展望一主に木造断熱外皮 の耐久性向上を目的とした技術・研究動向一, 第 54 回日本木材学会大会 (札幌) 生物劣化研究会, 2004 年 8 月

6 鈴木大隆, 北谷幸恵, 岩前篤, 永井久也, 鈴木憲太郎, 坂本雄三 : 断熱壁体 中の木材のダメージファンクション開発に向けてー主に断熱壁体の湿害防止の 観点からー, 日本建築学会環境工学委員会 熱環境運営委員会第 35 回熱シンポ ジウム「湿気研究の実用的展開」,pp141-144,2005 年 11 月

7 Hirotaka Suzuki ,Yukie Kitadani, Kentaro Suzuki, Atsushi Iwamae, Hisaya Nagai; Development on Damage Functions of Wood Decay for Building Envelope Design,THE INTERNATIONAL RESEARCH GROUP ON WOOD PRESERVATION Section5 Environmental aspects,2005.4.28

\section{参考文献}

1) Kentaro Suzuki: Effect of Cyclic Change of Temperature on Fungal Growth and Mass Loss, The International Research Group on Wood Preservation, Document No.IRG/WP 94-10065,1994年

2) Paul I Morris, Jerrold E Winandy: Limiting Conditions for Decay in Wood System, The International Research Group on Wood Preservation, Document No.IRG/WP 02-10421, 2002年

3）鈴木憲太郎 : 含水率範囲毎のベイツガ材の腐朽について, 第 36 回木材学会大会 要旨集,p26,1986,4

4) 阿部恵子 : カビによる環境測定法,カビは空気環境を認識するセンサーである, 空気調和・衛生工学 69 巻,pp.519-525,1995

5 )大澤元毅,頼戸裕直,鈴木大隆 : 夏季条件における壁体の温湿度性状とその評 価に関する検討, $5^{\text {th }}$ Canada-Japan Housing RD Workshop Proceedings, pp.241-254, 1999 年 8 月

6) 本間義規,鈴木大隆,坂本雄三 : 梅雨期を含む夏期の基礎断熱床下空間の温湿度環 境-温暖地における基礎断熱工法に関する研究その 2, 日本建築学会計画系論文集 No. $530, \mathrm{pp} 25,2000$ 年 4 月

7）浅野猪久,夫,杉山英男,大熊幹章,岡野健 : 木材と住宅 学会出版センター,1979 8) 建設省住宅局住宅生産課監修 : 木造住宅-而久性向上の手引き,丸善出版社,1982 9）農林水産省林産試験場監修 : 木材工業ハンドブック改訂 3 版, 丸善,1982

10) 今村祐嗣ほか：建築に役立つ木材・木質材料学, 東洋書店,1997

11）鈴木憲太郎：防腐·防蟻対策と最新技術，住宅と木材 2001 年 3 月号，財）日本 住宅・木材技術センター

12) 建築基準法に基づく主要な告示「木材の基準強度を定める件(平成 12 年 5 月 31 日建告第 1452 号)

13）木材軸組工法住宅の許容応力度設計，(財)日本住宅・木材技術センター，2002.6 